\title{
Glyphosate Stimulates the Accumulation of N-Compounds, Grain Yield and Seed Vigor in Glyphosate-Resistant Soybean
}

\author{
Marcio S. Silva ${ }^{1}$, Gustavo R. F. Oliveira ${ }^{1}$, Edson Lazarini ${ }^{1}$, Marco E. Sá ${ }^{1}$, Lucas A. Souza ${ }^{2}$, Gilberto C. Justino ${ }^{3}$, \\ Aline R. Martins ${ }^{1} \&$ Liliane S. Camargos ${ }^{1}$ \\ ${ }^{1}$ School of Engineering, São Paulo State University (UNESP), Ilha Solteira, SP, Brazil \\ ${ }^{2}$ Goiano Federal Institute (IFGoiano), Rio Verde, GO, Brazil \\ ${ }^{3}$ Institute of Biological Sciences and Health, Federal University of Alagoas (UFAL), Maceió, AL, Brazil \\ Correspondence: Liliane S. Camargos, Department of Biology and Zootechny, School of Engineering, São Paulo \\ State University (UNESP), Rua Monção, 226, Zona Norte, Ilha Solteira, São Paulo 15385-000, Brazil. E-mail: \\ camargos@bio.feis.unesp.br
}

Received: September 17, 2017

Accepted: December 9, 2017 Online Published: January 15, 2018

doi:10.5539/jas.v10n2p157

URL: https://doi.org/10.5539/jas.v10n2p157

\begin{abstract}
Glyphosate-resistant (GR) soybean is widely used in agriculture, however, plants exposed to herbicide show physiological changes. This study investigated the effect of treatments with glyphosate on the metabolism of $\mathrm{N}$ compounds, crop yield and physiological quality of seeds in GR soybean. The plants were grown in field experiment, located in the city of Selvíria, MS, Brazil. Glyphosate was applied postemergence at $\mathrm{V}_{4}$ crop stage in a dose-response, including four rates $\left(0 ; 360 ; 720\right.$ and $1440 \mathrm{~g}$ e. a. ha $\left.{ }^{-1}\right)$ with four replicates. Crop yield, physiological and biochemical features were determined. The results revealed previously unreported stimulant effects of glyphosate on GR soybean plants. Glyphosate changed the ureide shape in leaves, but did not change the concentration of total ureides, indicating maintenance of biological nitrogen fixation in plants exposed to herbicide. Amino acids concentration increased in plants submitted to higher doses. GR soybean showed higher crop yield and seed vigor with increased glyphosate doses. The results of this study indicate that glyphosate does not cause stress to the plant; however, it modulates a distinct response in plant development due to the protective gene inserted. This study can serve as a matrix for additional studies in order to seek clarification of responses of resistant/tolerant plants to glyphosate.
\end{abstract}

Keywords: plant development, transgenic soybean, herbicide, nitrogen

\section{Introduction}

Soybean (Glycine max (L.) Merrill) stand out as one of the world's main commodities, with the United States being the largest producer nations, followed by Brazil and Argentina (Krenchinsk et al., 2017). Much of the success of soybean cultivation worldwide occurs due to the development of transgenic cultivars, with about $93 \%$ of soybean cultivars in Brazil being transgenic (Clive, 2014).

Soybean cultivars with the Roundup Ready ${ }^{\circledR}$ gene was developed through genetic engineering, aiming at improvements in integrated management of weeds. Thus, after spraying crop with the herbicide, only the weeds are affected, while the lethal effect is absent in GR soybean. The gene inserted is from the soil bacterium Agrobacterium tumefaciens strain CP4, which encodes a variant enzyme of EPSPs, CP4-EPSPs, conferring GR soybean resistance to glyphosate (Franz et al., 1997).

Although GR soybean displays distinct resistance to glyphosate, little is known about its effect on physiological processes and plant development, since that there are other modes of action of glyphosate, not only specific inhibition of EPSPs (Franz et al., 1997; Reddy et al., 2004). Literature data show that glyphosate causes visual injury symptoms on GR soybean plants (Zobiole et al., 2012), altering the nutritional status, mainly, with symptoms of Zn, Fe and Mn deficiency (Johal \& Huber, 2009), reduction of photosynthetic efficiency and water use (Zobiole, 2010a, 2010b). However, in some non-transgenic plants subjected to low glyphosate doses, the stimulant effect is frequently observed (Cedergreen, 2008; Dalley \& Richard, 2010).

As glyphosate is widely used in crops (Duke et al., 2008) and the distinct resistance to glyphosate in GR soybean causes physiological changes (Zobiole et al., 2010a, 2010b), the hypothesis of this work is that GR soybean 
plants under treatments with glyphosate show the physiological and biochemical characteristics alterated, culminating with change in crop yield. Thus, the objective of the present study was to investigate the effects of treatments with glyphosate on the metabolism of $\mathrm{N}$ compounds, crop yield and physiological quality of seeds in GR soybean.

\section{Method}

\subsection{Study Site and Climate Data}

The experiment was conducted in the 2015/2016 season in an experimental localizated in Selvíria, Mato Grosso do Sul, Brazil $\left(55^{\circ} 22^{\prime} \mathrm{W}\right.$ and $\left.22^{\circ} 20^{\prime} \mathrm{S}, 335 \mathrm{~m}\right)$. According to the USDA classification, the soil is Rhodic Hapludox (Soil Survey Staff, 2010). Before the installation of the experiment, soil samples composed of 20 sub-samples, at 0.0-0.2 m layer, were collected to determine the chemical characteristics, in accordance with Raij et al. (1997): organic matter $22 \mathrm{~g} \mathrm{dm}^{-3} ; \mathrm{pH}(\mathrm{CaCl} 2)$ 5.1; $\mathrm{P}$ (resin) $20 \mathrm{mg} \mathrm{dm}^{-3} ; \mathrm{K} 2.6 \mathrm{mmolc} \mathrm{dm}^{-3}$; Ca $17 \mathrm{mmolc}$ $\mathrm{dm}^{-3} ; \mathrm{Mg} 12 \mathrm{mmolc} \mathrm{dm}^{-3}$ and bases saturation of $51 \%$. The climate is type Aw (Köppen classification) with annual precipitation average $1370 \mathrm{~mm}$. The average annual temperature is $23.5^{\circ} \mathrm{C}$ and relative air humidity $66 \%$ (annual average). During the experiment period, the average minimum and maximum temperatures were $21.9 \pm 1.5^{\circ} \mathrm{C}$ and $33.1 \pm 2.2{ }^{\circ} \mathrm{C}$, respectively. Additionally, periodic assessments of temperature and precipitation data in the experimental area were made. The data were obtained from a meteorological station of the experimental farm, located at $180 \mathrm{~m}$ of the experimental area (Figure 1).

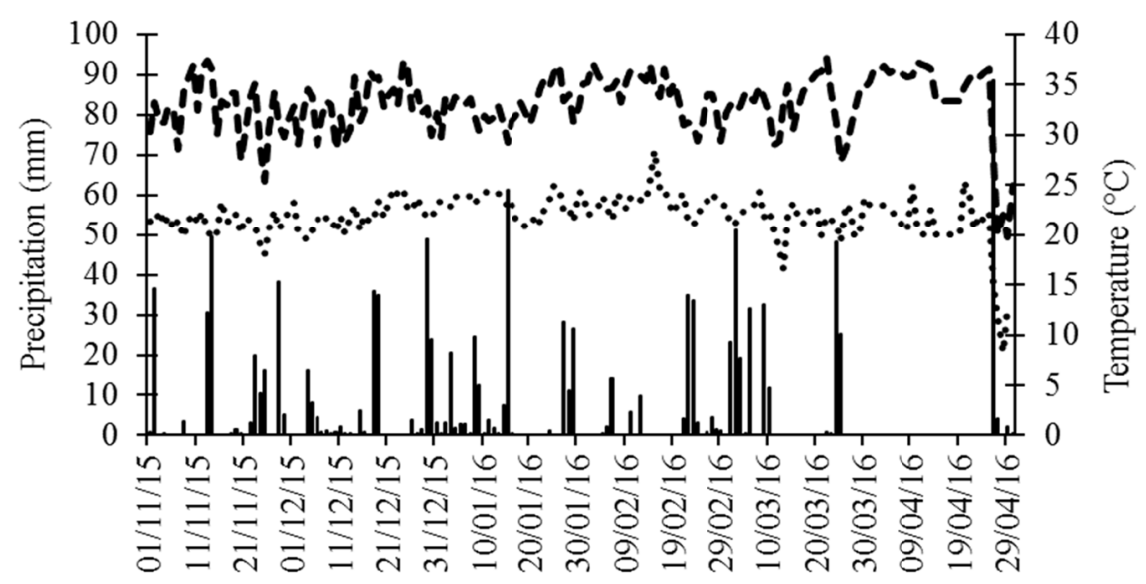

Precipitation $\quad$ - - Maximum temperature $\cdots . .$. Minimum temperature

Figure 1. Precipitation (mm), maximum temperature $\left({ }^{\circ} \mathrm{C}\right)$ and minimum temperature $\left({ }^{\circ} \mathrm{C}\right)$ during the experimental in 2015/2016 season agricultural crop

\subsection{Plant Cultivation}

Initially, the seeds were treated with a product containing carboxym+thiram, at a dose of $50+50 \mathrm{~g}$ (active ingredient) $100 \mathrm{~kg} \mathrm{seeds}^{-1}$. After drying the product, the application was made with peat-base inoculant aiming to achieve a minimum of $1.2 \times 10^{6}$ colony-forming units of Bradyrhizobium per seed, as recommended for tropical regions (Hungria et al., 2017).

The fertilization for sowing was performed according to soil analysis to obtain high yield using $300 \mathrm{~kg} \mathrm{ha}^{-1}$ of 04-20-20 formulation applied in the furrow seeding, according to Raij et al. (1997). On Nov. 16, 2015, mechanical seeding was carried out jointly with fertilizing, using the soybean cultivar BMX Potência RR in an area previously plowed and harrowed. The spacing between rows was $0.45 \mathrm{~m}$ and a density was 15 seeds per $\mathrm{m}$ with a population of 300,000 plants ha ${ }^{-1}$ ( $90 \%$ germination). The emergence of seedlings occurred on 21 Nov 2015. The experimental plots were set up by seven rows of $10 \mathrm{~m}$ and the three central rows were considered useful area, disregarding $1 \mathrm{~m}$ at both ends $\left(10.8 \mathrm{~m}^{2}\right)$.

The recommended dose of herbicide of $720 \mathrm{~g} \mathrm{ha}^{-1}$ (e. a. - equivalent acid) (Ludwig et al., 2011) was considered and on Dec. 14, 2016, at phenological stage $\mathrm{V}_{4}$ (Fehr et al., 1971), glyphosate was applied as follows: $\mathrm{T}_{0}-$ Control $\left(0\right.$ g e. a. ha $\left.{ }^{-1}\right) ; \mathrm{T}_{1}$ - underdose recommended $\left(360\right.$ g e. a. ha $\left.{ }^{-1}\right) ; \mathrm{T}_{2}-$ recommended dose $\left(720 \mathrm{~g}\right.$ e. a. ha $\left.{ }^{-1}\right)$ 
and $\mathrm{T}_{3}$ - overdose $\left(1440 \mathrm{~g}\right.$ e. $\left.\mathrm{a} . \mathrm{ha}^{-1}\right)$. The application of the herbicide was held with a costal sprayer (manual application) with volume of $200 \mathrm{~L} \mathrm{ha}^{-1}$. The source used was the herbicide Roundup ${ }^{\circledR}$ (trade name), whose formulation corresponds to composition: salt of isopropylamine $\mathrm{N}$-(phosphonomethyl) glycine $480 \mathrm{~g} \mathrm{~L}^{-1}$ ( $48 \% \mathrm{~m}$ $\left.\mathrm{v}^{-1}\right)$, equivalent acid of $\mathrm{N}$-(phosphonomethyl) glycine (glyphosate) $360 \mathrm{~g} \mathrm{~L}^{-1}\left(36 \% \mathrm{~m} \mathrm{v}^{-1}\right)$, and inert ingredients of $684 \mathrm{~g} \mathrm{~L}^{-1}\left(68 \% \mathrm{~m} \mathrm{v}^{-1}\right)$. The supplemental mechanical (manual) weed control was performed during the entire crop cycle, especially in the plots of the control treatment that was used only the manual weed control method.

\subsection{Extraction of N Compounds for Quantification and Qualitative Analysis of Amino Acids}

On Jan. 18, 2016, at the phenological phase $\mathrm{R}_{2}$ (Fehr et al., 1971), the first newly expanded leaf (from the main stem) was collected and later the samples were placed in plastic bags. Next, the plant material was taken to the lab and placed in a freezer for further analysis.

$\mathrm{N}$ compounds were extracted according to recommendations of Bielski and Turner (1966).

For $1 \mathrm{~g}$ of fresh material, $10 \mathrm{~mL}$ of MCW solution $\left(60 \% \mathrm{~mL}\right.$ Methanol, $25 \% \mathrm{~mL}$ Chloroform, $15 \% \mathrm{~mL} \mathrm{H}_{2} \mathrm{O}$ ) was added. The material was mashed and then centrifuged. After centrifugation, $1 \mathrm{~mL}$ of chloroform $+1.5 \mathrm{~mL}$ of $\mathrm{H}_{2} \mathrm{O}$ was added for each $4 \mathrm{~mL}$ supernatant. After $24 \mathrm{~h}$ under refrigeration for to phase separation, the water-soluble phase was used for the analysis of ureides, amino acids and ammonia.

It was added $10 \mathrm{~mL}$ of $\mathrm{NaOH} 0.1 \mathrm{~N}$ to the precipitate, which was subsequently homogenized and, after centrifugation, the supernatant was used for the analysis of total protein.

The extraction was performed in plants entirely dependent on $\mathrm{N}$ biological fixation for nutrient supply throughout the plant cycle.

\subsubsection{Quantitative Analysis of Total Ureides (Allantoin and Allantoic Acid)}

The Vogels and Van der Drift (1970) method was used to quantify changes in the concentration of ureides (allantoin and allantoic acid) in the leaf tissue. The method determined the amount of glyoxylate formed after hydrolysis from the reaction with potassium Ferritian and phenylhydrazinium. Allantoin was used as a quantification standard.

\subsubsection{Quantitative Analysis of Total Soluble Amino Acids}

The Yemm and Cocking (1955) method was used to quantify changes in the concentration of total soluble amino acids in the leaf tissue. Leucine was used as a quantification standard.

\subsubsection{Quantitative Analysis of Ammonia}

The McCullough (1967) method was used to quantify changes in the concentration of soluble ammonia in the leaf tissue. Leucine was used as a quantification standard.

\subsubsection{Quantitative Analysis of Total Protein}

The Bradford (1976) method was used to quantify changes in the concentration of proteins in the leaf tissue. BSA was used as a quantification standard.

\subsection{Quantification of Production Components}

On Apr. 6, 2016, ten plants were collected manually in a randomized manner from one of the rows in the useful area of the plot. The plant material was placed in bags and taken to a concrete yard for final drying. Subsequently, impurities were eliminated and manual measurements of the number of pods per plant, number of grains per pod, number of grains per plant and mass of 25 seeds were made.

\subsection{Estimation of Grain Yield}

On Apr. 6, 2016, plants in two rows of the useful area of the plot were harvested manually. The plants were placed in bags and taken to a concrete yard for final drying. Subsequently, the threshing and cleaning of the material were carried out in a stationary threshing machine. The grain samples obtained were placed in paper bags and the grain mass of each sample was measured with a precision scale. Afterward, moisture was determined (greenhouse method $-105 \pm 3{ }^{\circ} \mathrm{C} / 24 \mathrm{~h}$ ) for subsequent correction of grain mass to $13 \%$ humidity. Grain yield was estimated in $\mathrm{kg} \mathrm{ha}^{-1}$.

\subsection{Physiological Analysis of Seeds}

The seeds obtained to quantify production components were used to perform all the physiological analysis of seeds. 


\subsubsection{First Germination Count, Total Germination and Germination Speed Index}

The germination test was performed with 50 seeds per treatment, containing four repetitions each. The seeds were sown on germination paper moistened with distilled water at a ratio 3 -fold the weight of the dry paper. The seeds were then incubated in germination chambers, at constant temperature of $25{ }^{\circ} \mathrm{C}$. The counts were performed at 5 and 9 days after the test installation and the results were expressed as percentage of normal seedlings (Brasil, 2009). The test of germination speed index was determined according to the equation proposed by Krzyzanowski et al. (1999).

\subsubsection{Dry Matter Mass of Seedlings}

After the germination test, 10 seedlings for each repeat treatment were collected to determine the dry matter mass. The seedlings were taken to a forced ventilation oven at $80{ }^{\circ} \mathrm{C}$ for a period of $24 \mathrm{~h}$ (Krzyzanowski et al., 1999). After reaching constant weight, the material was weighed on an analytical scale.

\subsubsection{Electric Conductivity}

The test was conducted in accordance with the methodology proposed by Loeffler et al. (1988). Four replicates of 50 seeds were used, weighed and immersed in $75 \mathrm{~mL}$ of distilled water inside plastic cups at $25{ }^{\circ} \mathrm{C}$. After soaking for $24 \mathrm{~h}$, the reading of the electric conductivity of the solution was determined with a Digimed CD-20.

\subsubsection{Accelerated Aging}

Seeds were placed in plastic gerbox boxes, functioning as the mini-cameras and containing $40 \mathrm{~mL}$ of water at the bottom, which were kept at $41{ }^{\circ} \mathrm{C}$ for $60 \mathrm{~h}$. Afterward, four repetitions of 50 seeds were place to germinate following the method described above. The evaluation was carried out on the 4th day after sowing, according to Brasil (2009).

\subsection{Statistical Analysis}

The experimental design was a randomized block design with four treatments and four replications. The data were subjected to analysis of variance and compared by regression test at $5 \%$ probability using the software SISVAR $^{\circledR}$

\section{Results}

Glyphosate did not alter the concentration of total protein, total ureides, allantoin and soluble ammonia in the leaves in any of the treatments used in GR soybeans $(p>0.05)$ (Table 1). However, the concentration of total soluble amino acids in the leaves responded positively $(\mathrm{p}<0.01)$ in treated plants with higher doses of the herbicide (Figure 2). Glyphosate did not change total ureide accumulation in the leaves $(p>0.05)$. However, there was a change in the ureide shape in the foliar tissue, caused by the reduction in the allantoic acid concentration in leaves of plants subject to treatment with the underdose and recommended dose of herbicide ( $\mathrm{p}$ $<0.05$ ) (360 and 720 g e. a. ha ${ }^{-1}$, respectively). This condition reverted when plants were exposed to overdose of the herbicide (Figure 2).

Table 1. Protein contents $\left(\mu \mathrm{mol} \mathrm{g}{ }^{-1} \mathrm{FW}\right)$, total ureides $\left(\mu \mathrm{mol} \mathrm{g}{ }^{-1} \mathrm{FW}\right)$, allantoin $\left(\mu \mathrm{mol} \mathrm{g}{ }^{-1} \mathrm{FW}\right)$ and ammonia $\left(\mu \mathrm{mol} \mathrm{g}{ }^{-1} \mathrm{FW}\right)$ in leaves of GR soybean subjected to different treatments with glyphosate

\begin{tabular}{|c|c|c|c|c|}
\hline Treatment with glyphosate & Protein $^{(1)}$ & Total ureides ${ }^{(1)}$ & Allantoin $^{(1)}$ & Ammonium $^{(1)}$ \\
\hline 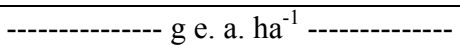 & \multicolumn{4}{|c|}{ - } \\
\hline 0 & 0.92 & 5127.35 & 2126.55 & 2.48 \\
\hline 360 & 1.50 & 3643.68 & 1827.76 & 2.46 \\
\hline 720 & 0.69 & 4398.05 & 2442.19 & 2.10 \\
\hline 1440 & 0.89 & 5995.90 & 2347.42 & 2.62 \\
\hline C.V. $(\%)$ & 32.60 & 31.22 & 32.25 & 17.84 \\
\hline
\end{tabular}

Note. Control (0 g e. a. ha $\left.{ }^{-1}\right)$; Glyphosate underdose recommended (360 g e. a. ha $\left.{ }^{-1}\right)$; Glyphosate recommended dose $\left(720\right.$ g e. a. ha $\left.{ }^{-1}\right)$; glyphosate overdose $\left(1440\right.$ g e. a. ha $\left.{ }^{-1}\right) ;^{(1)}$ Not significant in the $\mathrm{F}$ test at $5 \%$ probability; C.V. (\%) Coefficient of variation; Treatment with base in the equivalent acid of glyphosate (e. a.); $\mathrm{n}=16$.

There was no change in the number of pods per plant, grains per pod, grains per plant and mass of 25 seeds in any of the treatments $(p>0.05)$ (Table 2$)$. However, the grain yield of GR soybean was influenced positively 
with the increase of the glyphosate concentration $(\mathrm{p}<0.01)$, showing a better grain yield of $44 \%, 39 \%$ and $63 \%$ when exposed to concentrations of 360, 720 and 1440 g e. a. ha ${ }^{-1}$, respectively (Figure 3).

Table 2. Number of pods per plant, number of grains per pod, number of grains per plant and mass of $25 \mathrm{seeds}$ (g) in GR soybean plants subjected to different treatments with glyphosate

\begin{tabular}{lllll}
\hline Treatment with glyphosate & $\begin{array}{l}\text { Number of pods } \\
\text { per plant }^{(1)}\end{array}$ & $\begin{array}{l}\text { Number of grain } \\
\text { per pod }^{(1)}\end{array}$ & $\begin{array}{l}\text { Number of grain } \\
\text { per plant }^{(1)}\end{array}$ & Mass of 25 seeds ${ }^{(1)}$ \\
\hline---1 & & & \\
0 & 79.85 & 1.71 & 138.50 & 3.49 \\
360 & 67.68 & 2.14 & 132.05 & 3.55 \\
720 & 66.35 & 1.81 & 118.43 & 3.75 \\
1440 & 108.35 & 1.36 & 108.73 & 3.74 \\
C.V. $(\%)$ & 34.13 & 33.78 & 30.47 & 3.73 \\
\hline
\end{tabular}

Note. Control (0 g e. a. ha $\left.{ }^{-1}\right)$; Glyphosate underdose recommended (360 g e. a. ha $\left.{ }^{-1}\right)$; Glyphosate recommended dose $\left(720\right.$ g e. a. ha $\left.{ }^{-1}\right)$; glyphosate overdose $\left(1440\right.$ g e. a. ha $\left.{ }^{-1}\right){ }^{(1)}$ Not significant in the F test at $5 \%$ probability; C.V. (\%) Coefficient of variation; Treatment with base in the equivalent acid of glyphosate (e. a.); $\mathrm{n}=16$.

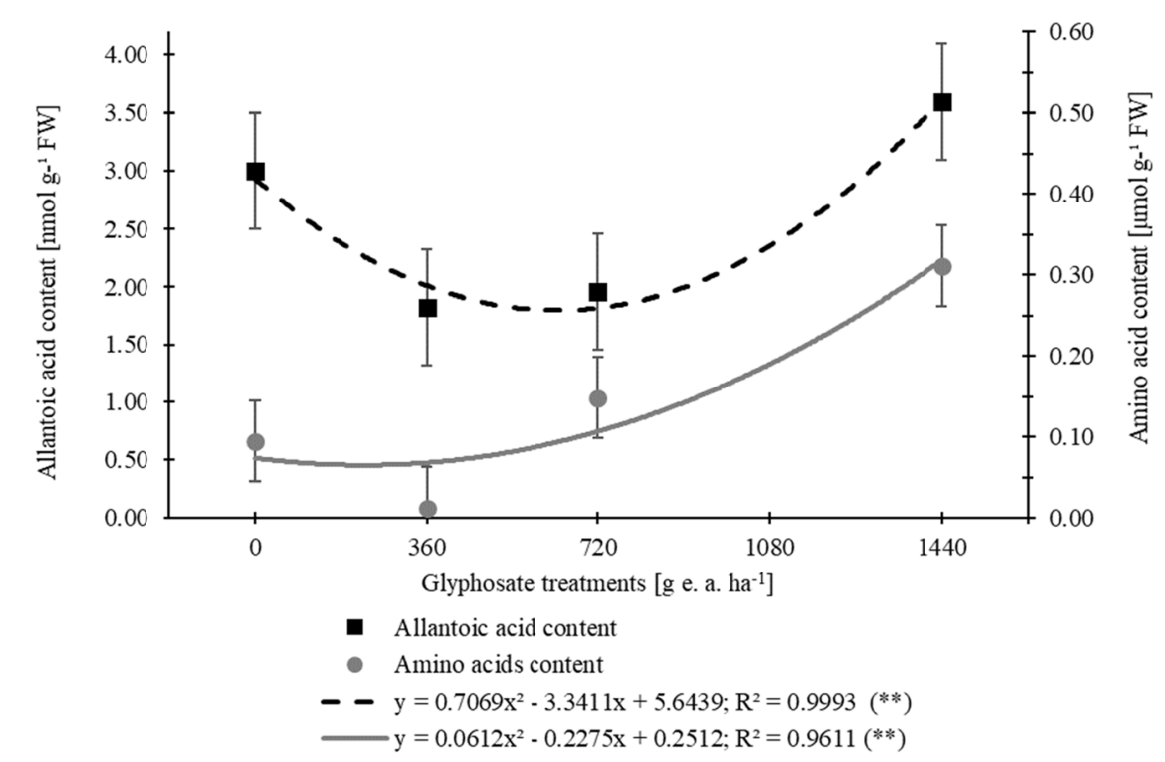

Figure 2. Allantoic acid concentration $(\mathrm{p}<0.05)$ and soluble amino acid $(\mathrm{p}<0.01)$ in leaves of GR soybeans subject to different glyphosate doses. $(* *)$ Regressions significant at $\mathrm{p}<0.01 ; \mathrm{n}=16$ 


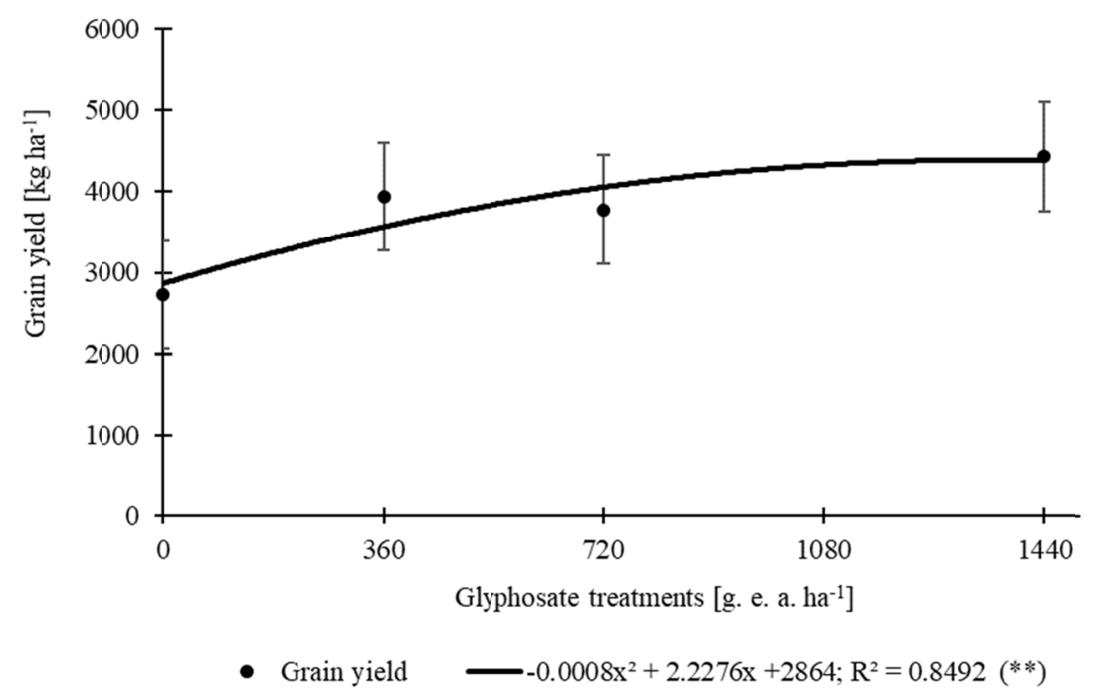

Figure 3. Grain yield GR soybeans due to the increase in glyphosate dose used $(\mathrm{p}<0.01)$. (**) Regression significant at $\mathrm{p}<0.01 ; \mathrm{n}=16$

Regarding the effects on the physiological quality of seeds, glyphosate did not alter the first germination count, total germination, germination speed index and dry matter mass of seedlings in any of the treatments $(p>0.05)$ (Table 3). On the other hand, in some physiological vigor analyses, seeds performed better, as observed on electrical conductivity of seeds that was reduced with the increase in herbicide concentration $(p<0.01)$ (Figure 4). Positive effects were also recorded in the accelerated aging test, with increased tolerance to damages caused by high temperature and humidity of $15 \%, 24 \%$ and $3 \%$ at concentrations of 360,720 and $1440 \mathrm{~g}$ e. a. ha ${ }^{-1}$, respectively $(\mathrm{p}<0.05)$ (Figure 4$)$.

Table 3. First germination count (\%), total germination (\%), germination speed index and seedling dry mass (mg) of seeds obtained from plants treated with different glyphosate doses

\begin{tabular}{|c|c|c|c|c|}
\hline Treatment with glyphosate & $\begin{array}{l}\text { First germination } \\
\text { count }^{(1)}\end{array}$ & Total germination $^{(1)}$ & $\begin{array}{l}\text { Germination speed } \\
\text { index }\end{array}$ & Seedling dry mass ${ }^{(1)}$ \\
\hline -------- g e. a. ha"-1 -------- & \multicolumn{3}{|c|}{ 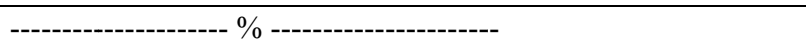 } & -------- mg --------- \\
\hline 0 & 71.00 & 71.00 & 7.10 & 30.98 \\
\hline 360 & 78.50 & 78.50 & 7.85 & 26.11 \\
\hline 720 & 64.00 & 64.00 & 6.40 & 22.59 \\
\hline 1440 & 71.50 & 71.50 & 7.15 & 25.88 \\
\hline C.V. $(\%)$ & 14.05 & 14.05 & 14.05 & 34.81 \\
\hline
\end{tabular}

Note. Control ( 0 g e. a. ha $\left.{ }^{-1}\right)$; Glyphosate underdose recommended (360 g e. a. ha $\left.{ }^{-1}\right)$; Glyphosate recommended dose $\left(720\right.$ g e. a. ha $\left.{ }^{-1}\right)$; glyphosate overdose $\left(1440\right.$ g e. a. ha $\left.^{-1}\right) ;{ }^{(1)}$ Not significant in the $\mathrm{F}$ test at $5 \%$ probability; C.V. (\%) Coefficient of variation; Treatment with base in the equivalent acid of glyphosate (e. a.); $\mathrm{n}=16$. 


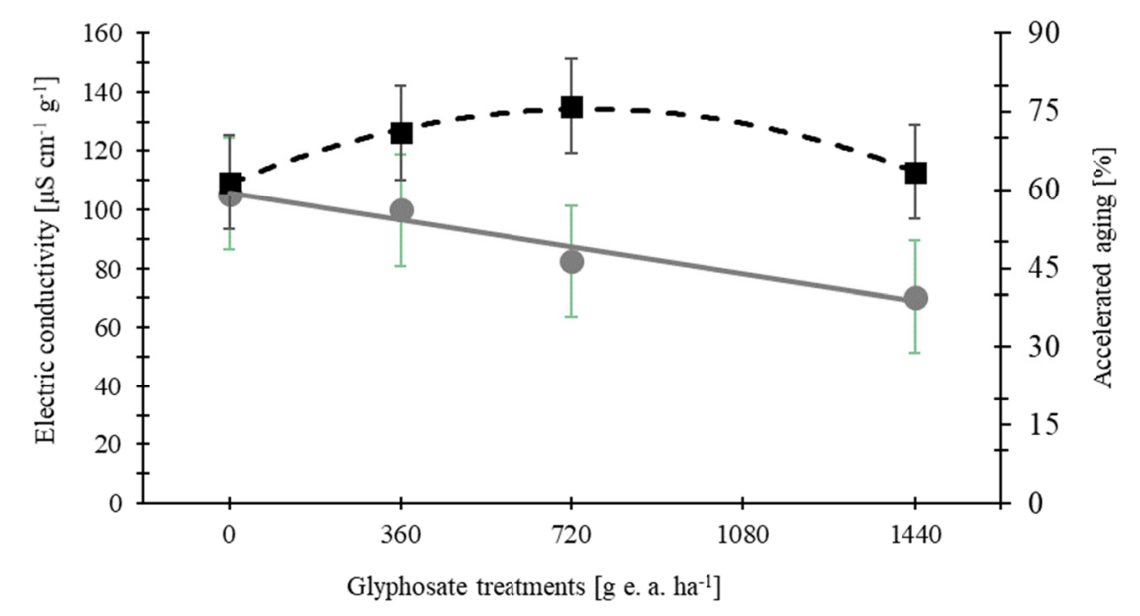

Electric conductivity
$\mathrm{y}=-12,279 \mathrm{x}+120,23 ; \mathrm{R}^{2}=0,9669$ (**)

- Accelerated aging

- - $\mathrm{y}=-5,5 \mathrm{x}^{2}+28,6 \mathrm{x}+37,75 ; \mathrm{R}^{2}=0,9376(* *)$

Figure 4. Electric conductivity $(\mathrm{p}<0.01)$ and accelerated aging of seeds $(\mathrm{p}<0.05)$ obtained from plants treated with different glyphosate doses. $(* *)$ Regressions significant at $\mathrm{p}<0.01 ; \mathrm{n}=16$

\section{Discussion}

This study highlights the importance of elucidating responses of a genetically modified plant, aiming to withstand exposure to glyphosate in an ecophysiological context. Previous studies from our research group showed that glyphosate moderately affected $\mathrm{N}$ fixation and assimilation, but there were no drastic metabolic changes for the amino acids, proteins, chlorophylls and ureides in vegetative stage of GR soybean (Bomfim et al., 2017); however, no data are available on the effects of glyphosate on the content of $\mathrm{N}$ compounds during the reproductive stage. As for qualitative variation in the form of ureides (Figure 2), there is no clear explanation in the literature, although some studies have reported this response depending on the $\mathrm{N}$ source in the medium (Camargos et al., 2009; Camargos \& Sodek, 2010). In this study, no changes were observed in concentrations of some $\mathrm{N}$ compounds in the leaves (Table 1), but rather an increased concentration of amino acids (Figure 2). Even with the qualitative change in the ureide shape in the leaves, the concentration of total ureides was not affected (Table 1).

Ureides are responsible for most $\mathrm{N}$ transported via the xylem to the shoot in soybean plants and are, therefore, used as signals of efficiency of the biological fixation of N (Herridge \& Peoples, 1990). This shows that the optimal levels of $\mathrm{N}$-fixation were kept, even in plants exposed to glyphosate, which are contrasting to studies that showed negative effects of glyphosate on fixation and nodulation in GR soybeans (Reddy \& Zablotowicz, 2003; Zobiole et al., 2011).

Due to the distinct resistance incorporated in GR soybean, the plant exposed to the herbicide displays resilience mechanisms to potentially harmful agent, not exempting effects on important in the processes of plant development. Transgenesis promotes an alternative route that aims to preserve the shikimic acid pathway, which is inhibited by specific action of glyphosate on the EPSPs enzyme, providing soybeans resistance to glyphosate (Zablotowicz \& Reddy, 2007). However, the literature reports that herbicides may alter the way the photoassimilates are allocated to different plant organs, due to its effect on plant development (Cedergreen et al., 2007).

Full flowering coincides with the peak of photoassimilates accumulation in the leaves, because the leaves are a strong drain until entrance of the vegetables into the reproductive stage (Soudry et al., 2005). Therefore, the higher status of $\mathrm{N}$-compounds in the leaves (Figure 2) are possibly related to the effect of herbicides on plant development (Cedergreen et al., 2007).

In order to protect the species in environments, in response to herbicide, senescence processes were anticipated in plants exposed to glyphosate, which subsidizes the greater grain yield in herbicide-treated plants (Figure 3). The modifications mentioned in the plant development pattern resemble the hormesis effect, as described by 
Calabrese and Baldwin (2008) that, under low phytotoxicity conditions, plants present responses that stimulate the development (Belz et al., 2010).

By comparison, the use of low glyphosate doses in sugar cane is a consecrated practice as a measure to accelerate the maturation process (Dalley \& Richard, 2010). Although these data refer to the non-transgenic plant, from the ecophysiology viewpoint, vegetables tend to accelerate their development under low phytotoxicity conditions (Calabrese \& Baldwin, 2008), aimed at the maintenance of specie as a strategy of phytogeographic perpetuation (Cedergreen et al., 2007).

In experiment using low glyphosate concentration, the hormesis effect is often seen in plants (Cedergreen, 2008; Dalley \& Richard, 2010); however, because GR soybean plants present the protective gene to glyphosate, AroA (Zablotowicz \& Reddy, 2007), the hormesis effect is observed at higher concentrations. With the process of accelerated monocarpic senescence, photoassimilates are distributed to high-demand sites, while they subsidize the positive effect on physiological vigor of seeds of plants treated, as observed in the electrical conductivity and accelerated ageing tests (Figure 4).

The electrical conductivity test indicates the integrity level of cell membranes due to the leachate quantity in the soaking solution, and the seed vigor is inversely proportional to the reading of electric conductivity (Hepburn et al., 1984; Marcos-Filho et al., 2001). The relative earliness of monocarpic senescence in treated plants caused the acceleration of photoassimilates distribution of source organs for the seed, and the reserve of seed is formed mainly by proteins and lipids (Bellaloui et al., 2015). The larger stocks of these substances in seeds resulted in the proper structuring of cell membranes, justified by the fact that proteins and lipids are essential to the integrity of biological membranes (Nelson \& Cox, 2014).

In line with the data on electric conductivity (Figure 4), seeds from treated plants showed better performance in the accelerated aging test (Figure 4), which confers seed tolerance to adverse conditions of high temperature and humidity (Marcos-Filho et al., 2001). The better performance of seeds of treated plants is attributed to a direct relationship between the amount of recently stocked reserve and physiological quality of seeds (Pereira et al., 2015), since glyphosate stimulated plant development in order to accumulate more reserve stock in seeds.

GR soybean seems to respond differently to the glyphosate action, not necessarily characterizing negative stress to the plant, but modulating one response to distinct plant development due to the protective gene inserted. Therefore, stimulant effect of glyphosate on GR soybean plants is clear. Evidences exist and are categorical, but new experiments at field level will be necessary to detail that process. Thus, the glyphosate may be applicated not only by control weed, but also by stimulate the GR soybean development.

\section{Acknowledgements}

The authors are thankful for the financial support received by the Fundação de Amparo à Pesquisa do Estado de São Paulo (FAPESP-Brazil, process $\mathrm{N}^{\circ}$ 2012/23266-3) and for the scholarship the scientific initiation (FAPESP-Brazil, process N $\mathrm{N}^{\circ}$ 2013/23984-6-MSS).

\section{References}

Bellaloui, N., Bruns, H. A., Abbas, H. K., Mengistu, A., Fisher, D. K., \& Reddy, K. N. (2015). Agricultural practices altered soybean seed protein, oil, fatty acids, sugars, and minerals in the Midsouth USA. Frontiers in Plant Science, 6, 1-14. https://doi.org/10.3389/fpls.2015.00031

Belz, R. G., Cedergreen, N., \& Duke, S. O. (2011). Herbicide hormesis - can it be useful in crop production? Weed Research, 51, 321-332. https://doi.org/10.1111/j.1365-3180.2011.00862.x

Bielski, R. L., \& Turner, N. A. (1966). Separation and estimation of amino acids in crude plant extracts by thin-layer electrophoresis and chromatography. Analytical Biochem., 17, 278-293. https://doi.org/10.1016/ 0003-2697(66)90206-5

Bomfim, N. C. P., Costa, B. G. P., Souza, L. A., Justino, G. C., Aguiar, L. F., \& Camargos, L. S. (2017). Glyphosate Effect on Nitrogen Fixation and Metabolization in RR Soybean. Journal of Agricultrual Science, 9(10), 114-121. https://doi.org/10.5539/jas.v9n10p114

Bradford, M. M. (1976). A rapid and sensitive method for the quantitation of microgram quantities of protein utilizing the principle of protein-dye binding. Analytical Biochemistry, 72, 248-254. https://doi.org/10.1016/ 0003-2697(76)90527-3

Brasil. (2009). Regras para análises de sementes. Ministério da Agricultura, Pecuária e Abastecimento (MAPA/ACS). 
Calabrese, E. J., \& Blain, R. (2008). Hormesis in plant biology. Environmental Pollution, 157, $42-48$. https://doi.org/10.1016/j.envpol.2008.07.028

Camargos, L. S., \& Sodek, L. (2010). Nodule growth and nitrogen fixation of Calopogonium mucunoides L. show low sensitivity to nitrate. Symbiosis, 51, 167-174. https://doi.org/10.1007/s13199-010-0063-5

Camargos, L. S., Aguiar, L. S., Carmezini, J. A., \& Azevedo, R. A. (2009). Variation in the Ureide Content of Jack Bean during the Reproductive Stages in Response to Nitrate. Brazilian Archives of Biology and Technology, 52, 581-585. https://doi.org/10.1590/S1516-89132009000300009

Cedergreen, N. (2008). Is the growth stimulation by low doses of glyphosate sustained over time? Environmental Pollution, 156, 1099-1104. https://doi.org/10.1016/j.envpol.2008.04.016

Cedergreen, N., Streibig, J. C., Kudsky, P., Mathiassen, S. K., \& Duke, S. O. (2007). The occurrence of hormesis in plants and algae. Dose-Response, 5, 150-162. https://doi.org/10.2203/dose-response.06-008.Cedergreen

Clive, J. (2014). Global Status of Commercialized Biotech/GM Crops: 2014. ISAAA Brief n. 49. ISAAA: Ithaca, NY.

Dalley, C. D., \& Richard, E. P. J. R. (2010). Herbicides as ripeners for sugarcane. Weed Science, 58, $329-333$. https://doi.org/10.1614/WS-D-09-00001.1

Duke, S. O., \& Powles, S. B. (2008). Glyphosate: A once-in-a-century herbicide. Pest Management Science, 64, 319-325. https://doi.org/10.1002/ps.1518

Fehr, W. R., Caviness, C. F., Burmood, D. T., Pennington, J. S. (1971). Stage of development descriptions for soybeans, Glycine $\max ($ L.) Merrill. Crop Science, 11, 929-931. https://doi.org/10.2135/cropsci1971.0011 183X001100060051x

Franz, J. E., Mao, M. K., \& Sikorski, J. A. (1997). Glyphosate: A unique global herbicide. American Chemical Society, Washington, D.C., USA.

Hepburn, H. A., Powell, A. A., \& Matthews, S. (1984). Problems associated with the routine application of electrical conductivity measurements of individual seeds in the germination testing of peas and soybeans. Seed Science and Technology, 12, 403-13. https://doi.org/10.1590/S0034-737X2013000600019

Herridge, D. F., \& Peoples, M. B. (1990). Ureide Assay for Measuring Nitrogen Fixation by Nodulated Soybean Calibrated by 15N Methods. Plant Physiology, 93, 495-503. https://doi.org/10.1104/pp.93.2.495

Hungria, M., Araújo, R. S., Silva Júnior, E. B., \& Zilli, J. E. (2017). Inoculum Rate Effects on the Soybean Symbiosis in New or Old Fields under Tropical Conditions. Agronomy Journal, 109, 1-7. https://doi.org/ 10.2134/agronj2016.11.0641

Johal, G., \& Huber, D. M. (2009). Glyphosate effects on diseases of plants. European Journal of Agronomy, 31, 144-152. https://doi.org/10.1016/j.eja.2009.04.004

Krenchinski, H. H., Albrecht, L. P., Albrecht, A. J. P., Cesco, V. J. S., Rodrigues, D. M., Portz, R. L., \& Zobiole, L. H. S. (2017). Glyphosate affects chlorophyll, photosynthesis and water use of four Intacta RR2 soybean cultivars. Acta Physiology Plant, 63, 1-13. https://doi.org/10.1007/s11738-017-2358-0

Krzyzanowski, F. C., Vieria, R. D., \& França Neto, J. B. (1999). Vigor de sementes. Conceitos de teste Associação Brasileira de Tecnologia de Sementes.

Loeffler, L. M., Tekrony, D. M., \& Egli, D. B. (1988). The bulk conductivity test as an indicator of soybean seed quality. Journal Seed Technology, 12, 37-53. https://doi.org/10.1590/S0101-31222005000100004

Ludwig, M. P., Dutra, L. M. C., Lucca-Filho, O. A., Zabot, L., Jauer, A., \& Uhry, D. (2011). Populações de plantas na cultura da soja em cultivares convencionais e Roundup Ready ${ }^{\mathrm{TM}}$. Revista Ceres, 58, $305-313$. https://doi.org/10.1590/S0034-737X2011000300010

Marcos-Filho, J., Novembre, A. D., \& Chamma, H. M. C. P. (2001). Testes de envelhecimento acelerado e de deterioração controlada para avaliação do vigor de sementes de soja. Scientia Agrícola, 58, 421-426. https://doi.org/10.1590/S0103-90162001000200029

Mccullough, H. (1967). The determination of ammonium in whole blood by a direct colorimetric method. Clinica Chimica Acta, 17, 297-304. https://doi.org/10.1016/0009-8981(67)90133-7

Nelson, D. L., \& Cox, M. M. (2014). Principles of biochemistry of Lehninger (6th ed.). Artmed. New York, NY, USA. 
Pereira, W. A., Pereira, S. M. A., \& Dias, D. C. F. S. (2015). Dynamics of reserves of soybean seeds during the development of seedlings of different commercial cultivars. Journal of Seed Science, 37, 63-69. https://doi.org/10.1590/2317-1545v37n1142202

Raij, B. V., Cantarella, H., Quaggio, J. A., \& Furlani, A. M. C. (1997). Recomendações de adubação e calagem para o Estado de São Paulo (2nd ed., p. 285). IAC, Campinas.

Reddy, K. N., \& Zablotowicz, R. M. (2003). Glyphosate-resistant soybean response to various salts of glyphosate and glyphosate accumulation in soybean nodules. Weed Science, 51, 496-502. http://doi.org/ 10.1614/0043-1745(2003)051[0496:GSRTVS]2.0.CO;2

Reddy, K. N., Rimando, A. M., \& Duke, S. O. (2004). Aminomethylphosphonic Acid, a Metabolite of Glyphosate, Causes Injury in Glyphosate-Treated, Glyphosate-Resistant Soybean. Journal Agricultural Food Chemitry, 52, 5139-5143. https://doi.org/10.1021/jf049605v

Soil Survey Staff. (2010). Keys to soil taxonomy (11th ed.). USDA/NRCS, Washington, DC.

Soudry, E., Ulitzur, S., \& Gepstein, S. (2005). Accumulation and remobilization of amino acids during senescence of detached and attached leaves: in planta analysis of tryptophan levels by recombinant luminescent bacteria. Journal of Experimental Botany, 56, 695-702. https://doi.org/10.1093/jxb/eri054

Vogels, G. D., \& Van der Drift, C. (1970). Differential analysis of glycolate derivatives. Anal Biochemical, 33, 143-157. https://doi.org/10.1016/0003-2697(70)90448-3

Yemm, E. M., \& Cocking, E. C. (1955). Estimation of amino acids by ninhydrin. Analyst, 80, 209-213. https://doi.org/10.1039/AN9558000209

Zablotowicz, R. M., \& Reddy, K. N. (2007). Nitrogenase activity, nitrogen content, and yield responses to glyphosate in glyphosate-resistant soybean. Crop Protection, 26, 370-376. https://doi.org/10.1016/j.cropro. 2005.05.013

Zobiole, L. H. S., Kremer, R. J., Oliveira Jr, R. S., \& Constantin, J. (2010a). Glyphosate affects photosynthesis in first and second generation of glyphosate-resistant soybeans. Plant and Soil, 336, 251-265. https://doi.org/ 10.1007/s11104-010-0474-3

Zobiole, L. H. S., Kremer, R. J., Oliveira Jr, R. S., \& Constantin, J. (2011). Glyphosate affects chlorophyll, nodulation and nutrient accumulation of "second generation" glyphosate-resistant soybean (Glycine max L.). Pesticide Biochemistry and Physiology, 99, 53-60. https://doi.org/10.1016/j.pestbp.2010.10.005

Zobiole, L. H. S., Kremer, R. J., Oliveira Jr, R. S., Constantin, J., Kremer, R. J., \& Biffe, D. F. (2012). Amino acid application can be an alternative to prevent glyphosate injury in glyphosate-resistant soybeans. Journal Plant Nutrition, 35, 268-287. https://doi.org/10.1080/01904167.2012.636130

Zobiole, L. H. S., Oliveira Jr, R. S., Kremer, R. J., Constantin, J., Bonato, C. M., \& Muniz, A. S. (2010b). Water use efficiency and photosynthesis of glyphosate-resistant soybean as affected by glyphosate. Pesticide Biochemistry and Physiology, 97, 182-193. https://doi.org/10.1016/j.pestbp.2010.01.004

\section{Copyrights}

Copyright for this article is retained by the author(s), with first publication rights granted to the journal.

This is an open-access article distributed under the terms and conditions of the Creative Commons Attribution license (http://creativecommons.org/licenses/by/4.0/). 